\title{
The Impact of Globalisation Towards Bank Performance in Malaysia
}

\author{
Logasvathi Murugiah $^{1} \&$ Mugeshmani Supramaniam ${ }^{1}$ \\ ${ }^{1}$ School of Economics, Finance and Banking, Universiti Utara Malaysia, Malaysia \\ Correspondence: Logasvathi Murugiah, School of Economics, Finance and Banking, Universiti Utara Malaysia, \\ Malaysia.
}

Received: September 16, 2020

Accepted: November 5, 2020

Online Published: February 6, 2021

doi:10.5430/rwe.v12n1p331

URL: https://doi.org/10.5430/rwe.v12n1p331

\begin{abstract}
The purpose of this study is to shed some crucial light on the relationship between globalisation and performance of the banking system in Malaysia. This study uses a range of bank-characteristic determinants (internal factors), macroeconomic determinants (external factors) and three different dimensions of globalisation including economic globalisation, social globalisation and political globalisation to explain local commercial bank performance in Malaysia. This study uses regression analysis based on the secondary data for local commercial banks in Malaysia. The period for this secondary data is 10 years which is from the year 2008 till 2017. This study indicates that there is strong evidence stating both economic and politic globalisation have negatively significant effects on the bank performance in Malaysia. Meanwhile, social globalisation shows an insignificant result on this. As for bank characteristics variables, credit risk shows a negatively significant result towards bank performance in Malaysia while bank size shows a positive and significant result towards bank performance in Malaysia. Sole macroeconomic variable which is GDP does not show any significant result towards the bank performance in Malaysia. Therefore, central bank of Malaysia should give some incentive training for local bankers on how to adopt new supervision and risk management. This will give the local bankers some new knowledge to handle better risk management and directly boost the bank performance. Besides that, banks should develop their credit risk management to overcome any default loans and for better financial performances. Banks in Malaysia also need to expand their businesses as larger banks give a larger facility which directly boots the bank performance. It is also recommended for Malaysian banks to improve their forecasting of macroeconomic fluctuations in future to achieve greater efficiency levels.
\end{abstract}

Keywords: Bank, POLS, ROE, Malaysia, KOF globalisation index

\section{Introduction}

In 1985, the term of "globalisation" was first utilized by Theodore Levitt. Theodore describes the vest changes that had taken places in the global economy over last a few decades. The fast and pervasive economic and financial changes had occurred in consumption, production and investment all around the world. Globalisation is the procedure by which the world is ending up progressively interconnected because of greatly expanded trade and cultural exchange. Globalisation has expanded the generation of products and ventures. The greatest organizations are not any more national firms yet multinational corporations with subsidiaries in numerous nations. Early thoughts of globalisation were that when the world large disintegrated economic units are integrated together to form a more closed circuit economic unit, the gains can be derived from speed, closeness and unity of regions (Ekong, 2016).

Therefore, research has demonstrated that banking system's soundness and stability altogether put it in a superior stead to pick up from business. Such a steady state is accepted to protect the banking system against trouble, contagious and moral hazard. It decides the proficiency and efficiency of the banking system.

However, there are many issues that been argued by other authors such as Sufian \& Habibullah (2012), Sohaib \& Ahmad (2013), Ghosh (2016), Sufian \& Kamarudin (2016), Nguyen \& Nguyen (2018) on the design of the globalisation matters for the performance of the domestic commercial banks. According to Horen \& Claessens (2009) there are many reason for bank become globalised which is through technology of communication, deregulation and more economic integration. Besides that, due to globalisation, the activities in banking have been attributed to institutional specific characteristics and better profit opportunity (Focarelli \& Pozzolo, 2005).

Conceptually, globalisation in banking sectors happens when the foreign banks penetrate into the domestic market. Foreign banks might influence the bank performance in positive ways or in harmful ways. Previous study such as 
Sufian \& Habibullah (2012), Sohaib \& Ahmad (2013), Sufian \& Kamarudin (2016), Nguyen \& Nguyen (2018) tends to agree that globalisation is giving an advantage to bank performance especially in the return on assets (ROA) and return on equity (ROE). However, Boot (1999) and Ghosh (2016) had argued that there is negative side of globalisation in banking sector.

According to Boot (1999), governments may wish to have largest institutions in their nations domestically owned. So, it is also being argued that globalisation by bringing up foreign bank in the concentrated market might implies loss to domestic banks as it brings losses of a significant share to the advantages of foreign investors. Foreign banks also might give a high competition to domestic banks when it come into globalisation. This might reduce the banks performance domestically.

Besides that, regarding potential damages, foreign banks are regularly blamed for stimulating outflow of capital from the host country. Hence, when a country in a hard time, foreign banks might facilitate economic crisis, financial stability due to the outflow of capital from the host country (Ghosh, 2016). This will indirectly affect the bank performance of a country.

It comes to an understanding that regulation and a good supervision is vital for both domestic and foreign banks. However, deregulations might happen due to the impact of globalisation. According to Ghosh (2016), when the restriction of foreign banks in reduces, it may imply border efforts to deregulate the domestic banking sector in a sector. This might create a risky environment and indirectly affects the banking performance overall in a country (Cetorelli \& Goldberg, 2012).

However, some author such as Tschoegl (2004) counters the arguments above. During economy emergency, domestic depositors frequently pull back their deposits from foreign banks in which they have lost certainty and redeposit their assets in less risky banks, such as domestic ones. During emergency, the branches of domestic banks in a country will directly attract the attention of the depositors especially the banks with a great and better regulation system (Tschoegl, 2004).

Besides that, globalisation might give a stable credit supply when the parents' banks of the foreign countries back up the host's country banking industry during crisis. In addition, foreign banks might increase the bank performance by bringing up advance technologies, better supervision regulation and a good risk management system through globalisation. This will eventually raise the competition level of host nation's banking industry. Detragiache, Tressel, \& Gupta (2008) mentions that through globalisation, foreign bank can be considered safer than domestic back because they have parent banks to back them up, especially during financial crisis.

In addition, economic integration and profit opportunity are driving forces of bank globalisation. Nevertheless, economic integration and profit opportunity might be different depending on the home countries of the banks due to the politic, economy and social factors of the country and the bank culture itself. Thus, this study also builds an empirical model to measure the performance of the bank based on the internal factor which includes the bank-specific and also measures the external factors which includes the macroeconomic factors.

Based on the contrasting arguments on the positives and negatives sides of globalisation towards bank performance, a research and study on the impact of globalisation on the bank performance is still lacking. Thus, a good investigation of this topic and area gives a stable and good out coming of the impact of globalisation towards the bank performance.

Hence, the objectives of this study are (i) to examine the bank specific characteristic that may influence the Malaysian bank performance; (ii) to analyse the effect of macroeconomic conditions towards the performance of Malaysian banking sector and (iii) to investigate the relationship of globalisation on the performance of Malaysian banking sector.

\section{Literature Review}

\subsection{Eclectic Theory}

The eclectic theory is developed by Dunning (1977) and demonstrated a great degree productive mind-set about multinational enterprises (MNEs) and has inspired a lot of studies and applied work in banking, economics and international business. The eclectic paradigm is also called as OLI. "OLI" is the combination for Ownership, Location, and Internalization, OLI are the three potential advantages of favourable position that may underlie a company or bank's choice to become international. Ownership advantages is intended to address the subject and question of why a few firms yet not others travel to another country and recommend that a successful MNE and banks has some firm-specific advantages which enable it to conquer the operating costs in foreign nation. While, 
location advantage is intended to address the question of where a MNE plans to locate. Finally, international advantages impact on how a firm operate in foreign nation such as monitoring costs.

The eclectic theory is directly connected to this study in finding the effects of globalisation towards Malaysian commercial bank's performance. This theory indicates that there are three important factors to look up before internationalisation or globalisation happens. Based on the theory, it shows several advantages for a country in expending their firms and banks. In summary, eclectic theory shows the advantages of globalisation for firms and banks if it follows and have three main advantages which is the ownership advantages, location advantages and the international advantages. Therefore, this theory is very beneficial in understanding the advantages of foreign banks entering the domestic country through globalisation which directly affects the local commercial banks which is accordance to the objective of this study.

\subsection{Past Studies}

Sufian \& Habibullah, (2012) finds that there a significant and positively affects towards the bank performance in China in the year 2012. They believed that economic globalisation gives a huge profitability towards the banks in China as it is statistically significant at $1 \%$ level and believed that capital account liberalisation is normally joined by liberalisation of financial services sector which brings a great prominent rivalry, destroys monopolistic profits, and it indirectly driving down franchise value of local financial institutions. Besides that, Sufian \& Kamarudin, (2016) finds that the results are matching with Sufian \& Habibullah (2012) research. They conducted their studies based on the one country only which is South Africa in the year 2016. Most recently, Nguyen \& Nguyen (2018), finds that there are significant and positive effects towards bank performance in Vietnam.

Sufian \& Habibullah (2012), indicates that social globalisation gives a positive and significant affect towards bank performance. Social Globalisation index is divided into three indicators namely personal contacts (Pers_Con), information flows (info_flow), and cultural proximity (Cul_Prox). This is interesting to find that all the 3 indicators show positively significant sign. This indicates that China has a good banking system with outstanding social integration that expressively promotes Chinese banks' performance. Recently, Nguyen \& Nguyen (2018) conducted a study on the impact of globalisation towards the bank performance in Vietnam. The result is equivalent with the result shown by Sufian \& Kamarudin (2016) where it also shows a negatively significant result towards bank performance. Nguyen \& Nguyen (2018) believed that all the aspects of life in Vietnam had been affected due to the excessive spread of western culture in the country.

Sufian \& Habibullah (2012) proves that there are positive and significant effects on politic globalisation towards bank performance. Sufian \& Habibullah (2012) has conducted a research on globalisation and bank performance in China. According to Dreher (2006), politic integration might influence the economic growth. However, not all the studies show a positively significant result. There are some studies shows a different result. For instance, Nguyen \& Nguyen (2018) conducted a study in Vietnam with a title of Globalisation and bank performance in Vietnam. The study exerts negative and significant result on globalisation towards bank performance.

There are some studies that shows a positive and significant sign on the impact of credit risk towards bank performance Zhang, Jiang, Qu, \& Wang (2013), Abiola \& Olausi (2014) and Syafri (2012) are some of the previous studies that shows a positive and significant effects on credit risk (CR) towards bank performance. However, credit risk (CR) tend to have a negative coefficient as bad loans employs regressive impact on bank performance and most researchers expects to have a negative and significant result on their test. According to Miller \& Noulas, (1997), the higher the exposure of banks or financial institution in giving high risk loans, the greater accumulation of unpaid loans and this will directly lower the profitability of the banks.

Sufian \& Kamarudin, (2016) shows a positively significant result on the bank size towards the bank performance. This is because large banks tend to have better position as they have a better reputation (Sufian \& Kamarudin, 2016). Prior study from Athanasoglou, Brissimis, \& Delis (2008) suggests that by increasing the size of banking firm, marginal cost can be saved. However, the effects of rising bank's size performance might be positive at a limit. Beyond the point, the size could be negative due to governmental and other reason (Eichengreen \& Gibson, 2001).

According to Said \& Tumin, (2011), higher economic growth urges banks to lend more and grants them to charge higher margins and enhancing the nature of their assets. It is expected to have a positive effect of development in GDP on profitability of banks believed by Kanwal \& Nadeem, (2013); Zhang \& Daly (2014); Hailegebreal (2016) and Sufian \& Kamarudin, (2016). However, the results differ with the study made by Nguyen \& Nguyen (2018). The coefficient of LGDP found by them is negative and statistically significant at 1 percent. 


\section{Methodology}

This study utilized the quantitative research approach by gathering and investigating secondary data to fulfil the research objectives and to obtain an answer for research questions. The secondary data is retrieve from KOF globalisation index (KOF globalisation index is also known as KOF Konjunkturforschungsstelle by KOF Swiss Economic Institution. The KOF Globalisation Index measures the economic, social and political dimension to globalisation. It is used in order to monitor changes in the level of globalisation of different countries over extended periods of time. The current KOF Globalisation Index is available for 185 countries and covers the period from 1970 until $2017 . \quad$ KOF Globalisation Index: https://kof.ethz.ch/en/forecasts-and-indicators/indicators/kof-globalisation-index.html), published annual report, Thomson Reuters's data stream and World Bank database. The data is collected for 10 years which is from the year 2008 till the year 2017. This study identified eight local commercial banks in Malaysia as sample units. Based on the data collected, return on equity (ROE) is used as dependent variable proxy for bank performance while economic globalisation, social globalisation, politic globalisation, credit risk, bank size and GDP are the independent variables.

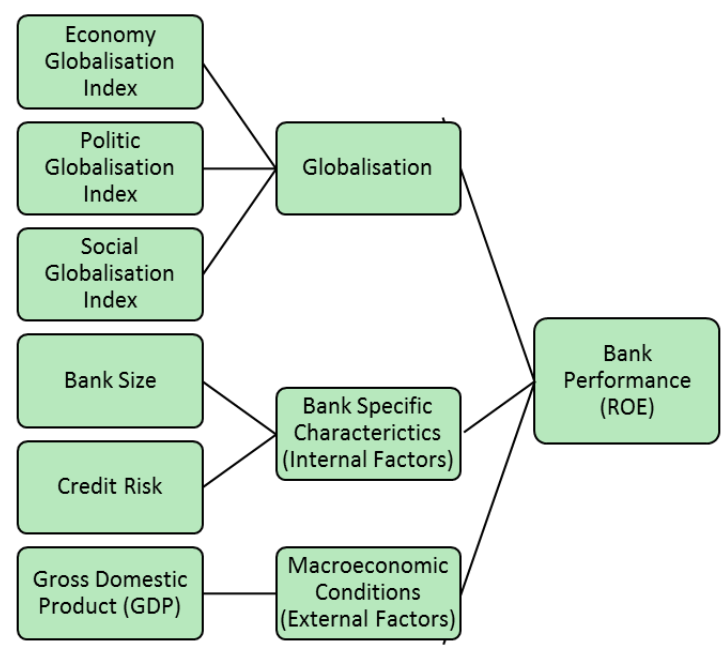

Figure 1. The theoretical framework of the study

This study utilized descriptive analysis as to portray the basic features of the information or data in an investigation. Furthermore, regression diagnostic or assumptions is vital to be check before proceeding to regression analysis. The assumptions that been used are normality, linearity, multicollinearity and homogeneity. All these assumptions are conducted on SPSS software version 25. Finally, the best prediction of dependent variable and independent variables can be measure through regression result. This study uses pooled ordinary least square (POLS) to perform multiple regression analysis.

\subsection{Regression Equitation Model}

$$
\mathrm{ROE}=\beta 0 \mathrm{j}, \mathrm{t}+\beta 1 \mathrm{X} 1+\beta 2 \mathrm{X} 2+\beta 3 \mathrm{X} 3+\beta 4 \mathrm{X} 4+\beta 5 \mathrm{X} 5+\beta 5 \mathrm{X} 6+\mu \mathrm{it}
$$

Where,

- $\quad \mathrm{ROE}=$ Return on equity

- $\beta 0=$ Constant

- $\mathrm{j}=$ individual bank

- $\mathrm{t}=$ time period

- $\mu=$ error term

- $\mathrm{X} 1=$ Credit risk

- $\quad \mathrm{X} 2=$ Bank size

- $\mathrm{X} 3=$ Gross domestic product 
- $\mathrm{X} 4=$ Economic globalisation

- $\mathrm{X} 5=$ Social globalisation

- $\quad \mathrm{X} 6=$ Politic globalisation

\section{Finding and Discussion}

\subsection{Descriptive Analysis}

Table 1. Descriptive statistics

\begin{tabular}{lllll}
\hline Variable & Minimum & Maximum & Mean & Std. Deviation \\
\hline ROE & 3.13 & 27.35 & 13.1670 & 4.64893 \\
\hline Economic Globalisation & 67.96 & 81.46 & 71.4310 & 4.32164 \\
\hline Social Globalisation & 73.81 & 81.38 & 78.8960 & 2.65821 \\
\hline Politic Globalisation & 83.42 & 86.50 & 85.5050 & 1.03375 \\
\hline Credit Risk & -.00198 & .01251 & .0032345 & .00332321 \\
\hline Bank Size & 17.13 & 20.45 & 18.8437 & .86778 \\
\hline GDP & .98 & 1.70 & 1.2589 & .21327 \\
\hline $\mathrm{N}$ & 80 & & & \\
\hline
\end{tabular}

As shown in the Table 1, the descriptive analysis states that variables have 80 observations. ROE has the mean value of 13.1670 while the maximum is value is 27.35 and the minimum value is 3.13 . The standard deviation of ROE is 4.64893. Mean value for economic globalisation, social globalisation, politic globalisation, credit risk, bank size and GDP are 71.4310, 78.8960, 85.5050, 0.003234, 18.8437 and 1.2589 respectively. The standard deviation for economic globalisation, social globalisation, politic globalisation, credit risk, bank size and GDP are 4.32164, $2.65821,2.65821,1.03375,0.0033232,0.86778$ and 0.21327 respectively. As overall, ROE has the highest standard deviation and largest variation between the minimum and maximum among all the variables. ROE has the maximum value of 27.35 and minimum value of 3.13. This implies that from the mean of ROE, the dispersion is more spread for ROE compared to other variables.

Additionally, this study runs regression diagnostic tests before proceeding to regression analysis. The assumptions that been used are normality, linearity, multicollinearity and homogeneity. The results shown that all assumptions analysis is not violated and therefore further analysis can be conducted.

\subsection{Regression Analysis}

Table 2. Coefficient analysis

\begin{tabular}{|c|c|c|c|}
\hline \multirow[t]{2}{*}{ Model } & Standardized Coefficients & \multirow[t]{2}{*}{$\mathrm{t}$} & \multirow[t]{2}{*}{ Sig. } \\
\hline & Beta & & \\
\hline (Constant) & & 2.932 & .004 \\
\hline Economic Globalisation & -1.107 & -4.645 & .000 \\
\hline Bank Size & .420 & 4.270 & .000 \\
\hline Credit Risk & -.386 & -3.616 & .001 \\
\hline Politic Globalisation & -.636 & -2.771 & .007 \\
\hline Social Globalisation & -.291 & -.755 & .453 \\
\hline GDP & -.101 & -1.067 & .290 \\
\hline Adjusted R Square & .334 & & \\
\hline $\mathrm{F}$ & 10.890 & & \\
\hline Sig & .000 & & \\
\hline
\end{tabular}


Based on the Table 2, the adjusted R-square shows 0.334 or $33.4 \%$ of independent variables that able to explain the dependent variable in this study. Meanwhile, ANOVA analysis, the significant value shows $1 \%$ level with the value of 10.890. This indicates that it is statistically significant relationship on predictors towards ROE.

Furthermore, table 2 also shows coefficient analysis for economic growth, social globalisation, politic globalisation, bank size, credit risk and GDP towards the dependent variable which is the ROE.

The result on the regression test shows that economic growth has negative relationship with the bank performance in Malaysia. This indicates that 1-unit increment in economic globalisation causes the bank performance of selected eight local conventional banks to decrease by 1.107 units with the assumption that all the other variables are remain constant. Based on the significance level $1 \%$, the alternate hypothesis that stated economic globalisation has significance relationship is accepted. In short, economic globalisation has a significance relationship with ROE of eight local conventional banks in Malaysia. According to previous study by Nguyen \& Nguyen (2018), the plausible reason for developing country such as Malaysia might have negative results because developing country considered rather weak and can barely compete in a globalised situation where capital account is open to liberalisation and the ownership of foreign banks in financial service sectors.

The result shown reflects that politic globalisation has a significantly negative relationship with the bank performance in Malaysia. Previous study from Vietnam conducted by Nguyen \& Nguyen (2018) also has the same negatively significant result towards bank performance. There is some possible reason on why the result is showing negative relationship towards ROE in Malaysia. Malaysia joined and signed many free trade agreements like other developing countries such as Vietnam, South Africa and many more. In fact, Malaysia had been a member of WTO since January $1^{\text {st }}, 1995$. This shows globalisation already happen long time ago in Malaysia through politic globalisation. These agreements bring plenty foreign banks to penetrate into Malaysian banking industry via politic globalisation. Foreign banks have done a good job in advertising to extend their market share. Thus, this competitive pressure given by the foreign bank triggers the local bank to do the same to remain competitive in the market. Malaysian local banks adopted Basel capital system, restructure the bank system and updated their banking technologies to compete in the market. However, this indirectly increases the operating cost and gives negative impact to the bank performance.

The finding shown that credit risk has a negative relationship with the bank performance in Malaysia. As the result, credit risk has a significance relationship with the ROE in local commercial banks in Malaysia. An accumulation of credit risk or unpaid loans will directly lower the profitability of the bank (Nguyen \& Nguyen, 2018). Some of the studies such as Ramlall (2009), Sohaib \& Ahmad (2013), Sufian \& Kamarudin (2016) and Nguyen \& Nguyen (2018) support this result.

The regression result reflects that bank has a positive and significant relationship with the bank performance in Malaysia. The plausible reason is that the larger banks in Malaysia might have good facilities, technologies which give a great advantage for banks to develop new products and this directly gives a positive impact towards bank performance. Much previous study such as Khrawish (2011), Sohaib \& Ahmad (2013) and Sufian \& Kamarudin (2016) supports this result.

Finally, the result shown by social globalisation and GDP is insignificant. The study conducted by Sohaib \& Ahmad (2013) and Combey \& Togbenou (2017) also shows insignificant results as same finding in this study.

\section{Conclusion}

The summary proved that based on the first objective, the finding indicates that both variables used as bank specific variable which is the credit risk and the bank size shows a significant correlation with bank performance. Second objective indicates that GDP has no significant effects towards the bank performance. This shows that GDP doesn't show any positive or negative effects on the performance of local commercial banks in Malaysia. Lastly, the impact of globalisation towards bank performance in Malaysia proved that economic globalisation and politic globalisation significantly related with eight local commercial banks in Malaysia but social globalisation shown insignificant result in this study.

This finding of this study will be a great exposure and enormous value for any academician and student of business, finance, banking and economics to obtain the information and data using KOF index. These data and information can also be used for future research in Malaysia regarding globalisation. Furthermore, this study gives some idea to banking industry on how to overcome problems through globalisation. Based on the results, it seems globalisation gives a negative impact towards bank performance in Malaysia. Local commercial banks can take a serious action based on the data and information to make a future plan to boosts their performance. For instance, training their 
employees to improve their expertise in order to compete with foreign banks might be a good outcome in future. Thus, the data and information of this study can create awareness of Malaysian banking industry to come out with a better risk management in order to compete with foreign banks. It is justifiable that the world is moving towards globalization in a fast track. This study demonstrates that globalization plays an important role in a nation, bank industry and to a people. A large portion of the banks are shutting the branches because of the advancement of technologies. Globalization brings an extraordinary headway towards technologies. A large portion of the bank services are in tip of our fingers. However, a few nations are absence of specialists in taking care of the services and advance technologies. It is important to keep in the mind that the headway of globalization brings the introduction of hackers globally. Thus, based on the result of the study, government can think of a strategy that gives and promote high education which principally focused on science and advance technologies. This will guarantee future people prepared to confront the worldwide rivalry.

\section{References}

Abiola, I., \& Olausi, A. S. (2014). The impact of credit management on the commercial banks performance in Nigeria. International Journal of Management and Sustainability, 295-306.

Akhisar, I., Tunay, B., \& Tunay, N. (2015). The effects of innovations on bank performance: the case of electronic banking services. Journal of Social and Behavioral Sciences, 369-375. https://doi.org/10.1016/j.sbspro.2015.06.336

Al Manaseer, M., Al-Dahiyat, M. A., Sartawi, I., \& Al-Hindawi, R. M. (2012). The impact of corporate governance on the performance of Jordanian banks. European Journal of Scientific Journal, 349-359.

Alexiou, C., \& Vogiazas, S. D. (2009). Determinants of bank profitability: Evidence from Greek banking sector. Economics Annals, 93-117. https://doi.org/10.2298/EKA0982093A

Alper, D., \& Anbar, A. (2011). Bank specific and macroeconomic determinants of commercial bank profitability: empirical evidence from Turkey. Business and Economics Research Journal, 139-152.

Athanasoglou, P., Brissimis, S., \& Delis, M. (2008). Bank-specific, industry-specific and macroeconomic determinants of bank profitability. Journal of International Financial Markets, Institution \& Money, 121-136. https://doi.org/10.1016/j.intfin.2006.07.001

Berger, A. N., DeYoung, R., Genay, H., \& Udell, G. F. (2000). Globalisation of financial institution: Evidence from cross-border banking performance. Brookings-Wharton Papers on Financial Services, 23-158. https://doi.org/10.1353/pfs.2000.0001

Boot, A. (1999). European lessons on consolidation in banking. Journal of Banking and Finance, 609-613. https://doi.org/10.1016/S0378-4266(98)00095-8

Burhonov, J. (2006). Islamic banking operations of commercial banks under Islamic Banking Scheme(IBS) of Malaysia: the performance analysis. Mahāwitthayālai Thammasāt: Faculty of Economics, Thammasat University.

Cetorelli, N., \& Goldberg, L. (2012). Banking globalization and monetary transmission. The Journal of Finance, 1811-1843. https://doi.org/10.1111/j.1540-6261.2012.01773.x

Chowdhury, M. A., \& Rasid, M. S. (2015). The determinants of the profitability of Islamic banks: a cross-sectional study from Asia and Africa. International Journal of Business and Globalisation, 375-388. https://doi.org/10.1504/IJBG.2015.071913

Combey, A., \& Togbenou, A. (2017). The bank sector performance and macroeconomics environment: empirical evidence in Togo. International Journal of Economics and Finance, 180-188. https://doi.org/10.5539/ijef.v9n2p180

Cooper, M. J., Jackson, W., \& Patterson, G. A. (2003). Evidence of predictability in the cross-section of bank stock returns. Journal of Banking \& Finance, 817-850. https://doi.org/10.1016/S0378-4266(01)00263-1

Davydenko, A. (2011). Determinants of Bank Profitability in Ukraine. Undegraduate Economic Review, 168-182.

Detragiache, E., \& Gupta, P. (2004). Foreign banks in emerging market crises: evidence from Malaysia. IMF Working Paper, 01-22. https://doi.org/10.5089/9781451855142.001

Detragiache, E., Tressel, T., \& Gupta, P. (2008). Foreign banks in poor countries: theory and evidence. The Journal of Finance, 2123-2160. https://doi.org/10.1111/j.1540-6261.2008.01392.x 
Dietrich, A., \& Wanzenried, G. (2011). Determinants of bank profitability before and during the crisis: Evidence from Switzerland. Journal of International Financial Markets, Institutions and Money, 307-327. https://doi.org/10.1016/j.intfin.2010.11.002

Dreher, A. (2006). Does globalization affect growth? Evidence from a new index of globalization. Applied Economics, 1091-1110. https://doi.org/10.1080/00036840500392078

Dunning, J. H. (1977). Trade, location of economic activity and the MNE: a search for an eclectic approach. The International Allocation of Economic Activity, 395-418. https://doi.org/10.1007/978-1-349-03196-2_38

Edirisuriya, P., \& Gunasekarage, A. (2015). Bank diversification, performance and stock market response: Evidence from listed public banks in South Asian countries. Journal of Asian Economics, 69-85.

Eichengreen, B., \& Gibson, H. (2001). Greek banking at the dawn of the New Millenial. CEPR Discussion Paper, 369-382.

Ekong, U. M. (2016). Globalization and the performance of commercial banks in Nigeria. Journal of Globalization Studies, 124-138.

Focarelli, D., \& Pozzolo, A. (2005). Where do banks expand abroad? An empirical analysis. The Journal of Business from University of Chicago Press, 2435-2464. https://doi.org/10.1086/497052

Gâdoiu, M. (2013). Advantages and limitations of the financial ratios used in the financial diagnosis of the enterprise. Scientific Bulletin - Economics Science, 87-95.

Garson, D. (2012). Testing statistical assumptions. North Carolina: Statistical Associates Publishing.

Ghosh, A. (2016). How does banking sector globalization affect banking crisis?. Journal of Financial Stabilty, 70-82. https://doi.org/10.1016/j.jfs.2016.07.003

Hadriche, M. (2015). Banks performance determinants: Comparative analysis between conventional and Islamic banks from GCC countries. International Journal of Economics and Finance, 169-177. https://doi.org/10.5539/ijef.v7n9p169

Hailegebreal, D. (2016). Macroeconomic and firm specific determinants of profitability of insurance industry in Ethiopia. Global Journal of Management and Business Research: C Finance, 467-484.

Hair, J., Money, A., Page, M., \& Samouel, P. (2007). Research method for business education + training. England: John Wiley and Sons.

Hassan, M., \& Bashir, A.-H. (2003). Determinants of Islamic banking profitability. 10th ERF Annual Conference (pp. 01-31). Morocco: ERF Paper.

Horen, N. V., \& Claessens, S. (2009). Being a foreigner among domestic banks: Asset or liability?. IMF Working Papers, 01-35. https://doi.org/10.5089/9781451874181.001

Kanwal, S., \& Nadeem, M. (2013). The impact of macroeconomic variables on the profitability of listed commercial banks in Pakistan. European Journal of Business and Social Sciences, 186-201.

Kaynak, E. (1986). Globalisation of banks: An integrative statement. International Journal of Bank Marketing, 03-08. https://doi.org/10.1108/eb010779

Khrawish, H. A. (2011). Determinants of commercial banks performance: Evidence from Jordan. International Research Journal of Finance and Economics, 148-159.

Mayer-Schönberger, V., \& Hurley, D. (2000). Globalization of communication. Goverance in a Globalizing World, 135-154.

Miller, S., \& Noulas, A. (1997). Portfolio mix and large bank profitability in the USA. Applied Economics, 505-512. https://doi.org/10.1080/000368497326994

Molyneux, P., \& Iqbal, M. (2005). Banking and financial systems in the Arab World. New York: Palgrave Macmillan. https://doi.org/10.1057/9780230512122

Nguyen, H. T., \& Nguyen, D. T. (2018). Globalisation and bank performance in Vietnam. Mlaysian Journal of Economic Studies, 49-70. https://doi.org/10.22452/MJES.vol55no1.3

Phua, K. L., \& Soo, K. S. (2004). What's ahead for Malaysia?: contemporary challenges and emerging trends. Subang Jaya, Selangor : Pelanduks. 
Ramadan, I. Z., Kilani, Q., \& Kaddumi, T. (2011). Determinants of bank profitability: Evidence from Jordan. International Journal of Academic Research, 180-191.

Ramlall, I. (2009). Bank-specific, industry-specific and macroeconomic determinants of profitability in Taiwanese banking system: under panel data estimation. International Research Journal of Finance and Economics, 160-167.

Rasiah, D. (2010). Review of literature and theories on determinants of commercial bank profitability. Journal of performance Management, 23-49.

Rijckeghem, C. V., \& Weder, B. (2000). Spillovers through banking centers: A panel data analysis. IMF Working Paper, 01-38.

Robin, I., Salim, R., \& Bloch, H. (2017). Cost efficiency in Bangladesh banking: does financial reform matter?. Journal of Applied Economics, 891-904. https://doi.org/10.1080/00036846.2017.1346361

Said, R. M., \& Tumin, M. H. (2011). Performance and financial ratios of commercial banks in Malaysia and China. International Review of Business Research Papers, 157-169.

Saleem, Z., \& Rashid, K. (2011). Mobile banking adoption in banking sector of Pakistan. Journal of Yasar University, 3538-3560.

Siddik, N. A., Sun, G., Kabiraj, S., Shanmugam, J., \& Yanjuan, C. (2016). Impacts of e-banking on performance of banks in a developing economy: empirical evidence from Bangladesh. Journal of Business Economics and Management, 1066-1080. https://doi.org/10.3846/16111699.2015.1068219

Smaoui, H., \& Salah, I. B. (2009). Profitability of Islamic Banks in the GCC Region. Journal of Business \& Policy Research, 16-44.

Sohaib, M., \& Ahmad, H. (2013). Impact of globalisation on the banking performance of Pakistan. International Journal of Management Sciences and Business Research, 84-91.

Sufian, F., \& Habibullah, M. S. (2012). Globalizations and bank performance in China. Research in International Business and Finance, 221-239. https://doi.org/10.1016/j.ribaf.2011.12.005

Sufian, F., \& Kamarudin, F. (2016). The impact of globalization on the performance of banks in South Africa. Review of International Business and Strategy, 517-542. https://doi.org/10.1108/RIBS-02-2016-0003

Sufian, F., Kamarudin, F., \& Nassir, A. M. (2017). Globalisation and bank efficiency nexus: empirical evidence from the Malaysian banking sector. An International Journal, 1269-1290. https://doi.org/10.1108/BIJ-09-2014-0090

Thakor, A., \& Besanko, D. (1987). Competitive equilibrium in the credit market under asymmetric information. Journal of Economic Theory, 167-182. https://doi.org/10.1016/0022-0531(87)90108-6

Tschoegl, A. (2004). Financial crises and the presence of foreign banks. Systemic Financial Distress: Containment and Resolution, 197-231. https://doi.org/10.1017/CBO9780511528521.008

Zhang, J., Jiang, C., Qu, B., \& Wang, P. (2013). Market concentration, risk-taking, and bank performance: Evidence from emerging economies. International Review of Financial Analysis, 149-157. https://doi.org/10.1016/j.irfa.2013.07.016

Zhang, X., \& Daly, K. (2014). The impact of bank-specific and macroeconomic factors on China's bank performance. The Chinese Economy, 5-28.

\section{Copyrights}

Copyright for this article is retained by the author(s), with first publication rights granted to the journal.

This is an open-access article distributed under the terms and conditions of the Creative Commons Attribution license (http://creativecommons.org/licenses/by/4.0/). 